\title{
Isolation of a rhabdovirus during outbreaks of disease in cyprinid fish species at fishery sites in England
}

\author{
K. Way*, S. J. Bark, C. B. Longshaw, K. L. Denham, P. F. Dixon, S. W. Feist, \\ R. Gardiner, M. J. Gubbins, R. M. Le Deuff, P. D. Martin, D. M. Stone, G. R. Taylor \\ Centre for the Environment, Fisheries and Aquaculture Science (CEFAS), Barrack Road, Weymouth, Dorset DT4 8UB, UK
}

\begin{abstract}
A virus was isolated during disease outbreaks in bream Abramis brama, tench Tinca tinca, roach Rutilis rutilis and crucian carp Carassius carassius populations at 6 fishery sites in England in 1999. Mortalities at the sites were primarily among recently introduced fish and the predominant fish species affected was bream. The bream stocked at 5 of the 6 English fishery sites were found to have originated from the River Bann, Northern Ireland. Most fish presented few consistent external signs of disease but some exhibited clinical signs similar to those of spring viraemia of carp (SVC), with extensive skin haemorrhages, ulceration on the flanks and internal signs including ascites and petechial haemorrhages. The most prominent histopathological changes were hepatocellular necrosis, interstitial nephritis and splenitis. The virus induced a cytopathic effect in tissue cultures (Epithelioma papulosum cyprini [EPC] cells) at $20^{\circ} \mathrm{C}$ and produced moderate signals in an enzyme immunoassay (EIA) for the detection of SVC virus. The virus showed a close serological relationship to pike fry rhabdovirus in both EIA and serum neutralisation assays and to a rhabdovirus isolated during a disease outbreak in a bream population in the River Bann in 1998. A high degree of sequence similarity ( $\geq 99.5 \%$ nucleotide identity) was observed between the English isolates and those from the River Bann. Experimental infection of juvenile bream, tench and carp with EPC cellgrown rhabdovirus by bath and intraperitoneal injection resulted in a $40 \%$ mortality of bream in the injection group only. The virus was re-isolated from pooled kidney, liver and spleen tissue samples from moribund bream. The field observations together with the experimental results indicate that this rhabdovirus is of low virulence but may have the potential to cause significant mortality in fishes under stress.
\end{abstract}

KEY WORDS: Fish $\cdot$ Rhabdovirus $\cdot$ Cyprinids $\cdot$ Histopathology $\cdot$ Enzyme immunoassay $\cdot$ RT-PCR

Resale or republication not permitted without written consent of the publisher

\section{INTRODUCTION}

Rhabdoviruses of the genus vesiculovirus are important pathogens of freshwater fishes in Europe, and are capable of inducing an acute haemorrhagic and contagious viraemia in susceptible species. One such vesiculovirus, spring viraemia of carp virus (SVCV), is recognised as having the most serious economic impact because of its association with major disease epizootics in cultured carp populations, and is notifiable to the Office International des Epi- zooties (OIE). Overt SVCV infections have been reported for at least 5 cyprinid fish species (Fijan et al. 1971, Kölbl 1975, Rudikov et al. 1975, Rudikov 1980) and in 1 silurid species, the sheatfish Silurus glanis (Fijan et al. 1984).

In contrast, the antigenically related pike fry rhabdovirus (PFRV) is not notifiable to the OIE as it is not considered to be as great a threat to fish stocks, having only been associated with infrequent outbreaks of clinical disease in pike Esox lucius hatcheries (Wolf 1988). Also, there are few reports of overt PFRV infection in 
cyprinid fish species. In Germany, PFRV has been isolated from diseased grass carp Ctenopharyngodon idella (Ahne 1975), tench Tinca tinca and white bream Abramis bjoernka (Ahne et al. 1982), but only the isolate from grass carp was confirmed to be pathogenic for its host (Ahne 1986).

In May 1998, high mortalities were reported in a population of common bream Abramis brama in the lower region of the River Bann in Northern Ireland. It was estimated that the eventual mortality totalled several thousand juvenile bream. Samples of dead bream were sent to the Veterinary Sciences Division Laboratory at Stormont, Belfast, where virological examination resulted in the isolation of a rhabdovirus from pools of kidney and spleen tissue. Preliminary serological typing at Stormont and at CEFAS, Weymouth, England, suggested that this was a strain of pike fry rhabdovirus (PFRV) (Rowley et al. 2001).

During the spring of 1999, Environment Agency officers reported outbreaks of clinical disease in coarse fish at 5 fishery sites in England. The fisheries had all recently stocked fish from a sixth site that had established a regular trade in a variety of coarse fish species. This site obtained fishes from several sites in the UK, including bream from the River Bann in Northern Ireland. This communication reports the findings from the diagnostic investigation of the disease outbreak.

\section{MATERIALS AND METHODS}

Fish samples. In late February 1999, the diagnostic virology laboratory at CEFAS, Weymouth, received a sample of viscera for virological examination from a mortality of tench at a fishery in southern England (Site A), and $10 \mathrm{~d}$ later further samples of fishes comprising 5 different cyprinid species, including tench, were obtained from Site A. Details of the species sampled are given in Table 1. Further mortalities were then reported during March and April 1999 in bream at 4 other fishery sites in England (Sites B, C, $\mathrm{D}$ and $\mathrm{E}$ ) and also in roach Rutilus rutilus at Site E. Again, samples were forwarded to CEFAS for virological examination. Live bream were also obtained from Site B and transported to CEFAS for postmortem and full diagnostic examination. All the reported mortalities were among fishes recently introduced to the 5 sites from a combined fishery and farm Site (F) in northern England. In early April 1999, samples of viscera were obtained from 7 different cyprinid species from holding facilities at Site F and, as the site discharges into a river, samples were also obtained from 5 species of wild river-fish (Site G) from below Site F.
Table 1. Fish species sampled at each of the 6 fishery sites (A to F) and river site (G) in England. Asterisk indicates species reported as recent introduction to sites

\begin{tabular}{|c|c|}
\hline Site & Fish species \\
\hline $\mathrm{A}$ & $\begin{array}{l}\text { Tench Tinca tinca*, roach Rutilus rutilus*, bream } \\
\text { Abramis brama, rudd Scardinius erythropthal- } \\
\text { mus, crucian carp Carassius carassius* }\end{array}$ \\
\hline $\mathrm{B}, \mathrm{C}, \mathrm{D}$ & Bream* only \\
\hline $\mathrm{E}$ & Bream $^{*}$, roach \\
\hline $\mathrm{F}$ & $\begin{array}{l}\text { Tench, bream*, roach, chub Leuciscus cephalus } \\
\text { crucian carp, grass carp Ctenopharyngodon } \\
\text { idella, common carp Cyprinus carpio }\end{array}$ \\
\hline $\mathrm{G}$ & $\begin{array}{l}\text { Chub, brown trout Salmo trutta, gudgeon Gobio } \\
\text { gobio, minnow Phoxinus phoxinus, bullhead } \\
\text { Cottus gobio }\end{array}$ \\
\hline
\end{tabular}

Histopathological examination. Tissue samples for examination were placed in $10 \%$ neutral buffered formalin. After 24 to $48 \mathrm{~h}$ fixation, the samples were transferred to $70 \%$ ethanol and processed for standard paraffin-embedding and sectioning. Cut tissue sections $(5 \mu \mathrm{m})$ on glass slides were stained with haematoxylin and eosin (H\&E) and examined using an Eclipse E800 photomicroscope (Nikon UK).

Virus isolation and identification. Tissue samples for virological examination were transported, unfrozen, in viral transport medium (Glasgow modification of minimal essential medium [GMEM] supplemented with $10 \%$ new-born calf serum, $2 \mathrm{mM}$ L-glutamine and $1 \%$ antibiotic + antimycotic solution; all Sigma) at a temperature not exceeding $12^{\circ} \mathrm{C}$. Virological examination followed procedures recommended for the isolation and identification of SVCV in the OIE diagnostic manual for aquatic animal diseases (OIE 2000). Pools of kidney, spleen and encephalon tissues from each of a maximum of 5 fish were homogenised with a pestle, mortar and sterile sand, resuspended in the original transport medium, and clarified by centrifugation at 2000 relative centrifugal force (RCF) for $20 \mathrm{~min}$. Supernatants were then diluted to 1:100 and 1:1000 (w/v) with culture medium (GMEM supplemented with $10 \%$ foetal bovine serum, $500 \mathrm{IU}$ $\mathrm{ml}^{-1}$ penicillin, $500 \mu \mathrm{g} \mathrm{ml}^{-1}$ streptomycin and $2 \mathrm{mM} \mathrm{L-}$ glutamine and inoculated onto Epithelioma papulosum cyprini (EPC; Fijan et al. 1983) cell monolayers in 12-well multidishes (Falcon). After $7 \mathrm{~d}$ incubation at $20^{\circ} \mathrm{C}$, monolayers showing no cytopathic effect (CPE) were diluted to $1: 10$ and 1:100 and subcultured onto fresh cells. Preliminary identification of viral CPE was by an amplified sandwich-ELISA following recommended procedures (OIE 2000) and using rabbit immunoglobulin (Ig) and biotinylated rabbit IgG specific to SVCV and PFRV and ExtrAvidin-conjugated 
horseradish peroxidase (Sigma). The identification was then confirmed by serum neutralisation assay using polyclonal rabbit antisera against SVCV and PFRV. These antisera were raised by intravenous injection of concentrated virus in the multiple inoculation programme described by Hill et al. (1981) for the production of a neutralising antibody to infectious pancreatic necrosis virus. Remaining portions of all processed homogenates were frozen at $-80^{\circ} \mathrm{C}$. Estimates of virus titres of any original samples found to be virus-positive were determined after 1 freeze/thaw cycle in EPC 96well multidishes according to the methods of Reed \& Muench (1938).

Virus transmission trials. Healthy 8 to $10 \mathrm{~cm}$ tench, 6 to $8 \mathrm{~cm}$ carp and 6 to $8 \mathrm{~cm}$ bream, obtained from a commercial producer, were distributed between six 251 static aquaria receiving a $30 \%$ change of $14^{\circ} \mathrm{C}$ freshwater every $7 \mathrm{~d}$. We tested 2 virus isolates in EPC-cell culture medium in the trial. The virus coded B062 was a tench isolate from Site A and Virus B125/1 was a bream isolate from Site E. Fishes were netted from the aquaria and either received a $4 \mathrm{~h}$ bath exposure to $10^{4.5} \mathrm{TCID}_{50}$ of virus $\mathrm{ml}^{-1}$ water or were anaesthetised before receiving an intraperitoneal (i.p.) injection with $0.1 \mathrm{ml}$ culture medium containing $10^{4} \mathrm{TCID}_{50}$ of virus. The allocation of fish species, virus and inoculation route is shown in Table 2a. Aquaria were checked daily over a $40 \mathrm{~d}$ period, and any moribund or dead fish examined for virus in selected tissues by the isolation procedures described above. Kidney and liver tissue from moribund or dead fish were also assayed using amplified SVCV and PFRV ELISAs and following recommended procedures (OIE 2000). At the end of the $40 \mathrm{~d}$ period, all remaining challenge and control fish were removed and examined for the presence of the virus. Samples for histopathological examination were obtained from moribund or freshly dead fish and from control fish.

In a second trial, healthy 7 to $11 \mathrm{~cm}$ tench, 6 to $10 \mathrm{~cm}$ roach, 6 to $9 \mathrm{~cm}$ bream, 6 to $12 \mathrm{~cm}$ dace Leuciscus leuciscus and 12 to $16 \mathrm{~cm}$ chub Leuciscus cephalus, obtained from a commercial producer, were distributed into five $40 \mathrm{l}$ flow-through aquaria receiving $15^{\circ} \mathrm{C}$ freshwater at $0.31 \mathrm{~min}^{-1}$. The 2 virus isolates B062 and B125/1 were again tested in this trial. We then netted $50 \%$ of the fish of each species from the aquaria; these were anaesthetised before receiving an i.p. injection with $0.1 \mathrm{ml}$ culture medium containing $10^{4} \mathrm{TCID}_{50}$ of virus. The remaining $50 \%$ of fish received no virus injection and constituted a cohabitant challenge. The allocation of fish species, virus and challenge route is shown in Table $2 \mathrm{~b}$. The aquaria were checked daily over a $50 \mathrm{~d}$ period and any moribund or dead fish were examined for virus in selected tissues by the isolation procedures described above; estimates of virus titres were determined in EPC 96-well multidishes according to the methods of Reed \& Muench (1938). At the end of the $50 \mathrm{~d}$ period, all remaining challenge and control fish were removed. All the challenge survivors and 5 each of the sham-injected and cohabitant controls were examined for the presence of the virus.

\section{RESULTS AND DISCUSSION}

\section{Outbreaks and gross pathological signs}

In February and March 1999, mortalities among bream, tench, roach and crucian carp at 5 fishery sites (A to E) in the UK began to appear 2 to $19 \mathrm{~d}$ after fish had been introduced from a farm/fishery site (F). Only fishes recently introduced to the 5 sites from Site $\mathrm{F}$ appeared to be affected and estimated daily mortalities were between 1 and $3 \%$. Prior to death, gross 
external pathological signs included fin erosion, scale loss, moderate to heavy fungal infection of skin and fins, skin ulcers, gill necrosis, extensive petechial haemorrhages and haemorrhages around the fin bases. However, the external signs were not consistent across sites. Moribund tench at Site A exhibited several of the clinical signs listed above but the only sign recorded for bream from Sites B and E was severe fin erosion. Internal signs were also inconsistent and included ascites, pale or discoloured (orange or yellow) liver, enlarged spleen, haemorrhaging in the gut epithelia and petechial haemorrhaging in liver, muscle and adipose tissue. Furthermore, the reports from the majority of the fishery sites indicated that many of the newly stocked fish were in poor condition and already suffering from fungal infections and extensive fin erosion when introduced to the site. Some external signs could be attributed to previous poor handling and transportation stress. For example, the haemorrhages noted around the pectoral and pelvic fins could well have been caused by netting and transport tank abrasion.

Parasitological examinations of skin scrapes and gill tissue were carried out for moribund and dead fish. In most (but not all) fishes, examination of the gill tissue revealed light to moderate infections of Trichodina sp. Myxobolus sp. and Dactylogyrus sp. were also seen in a few fish. Examination of skin scrapes from affected fish revealed Trichodina sp. and Chilodonella sp. and, less commonly, Ichthyophthirius multifiliis. Bacterial species known to be pathogens of fish (e.g. Aeromonas sp. and Flexibacter sp.) were also isolated from clinical

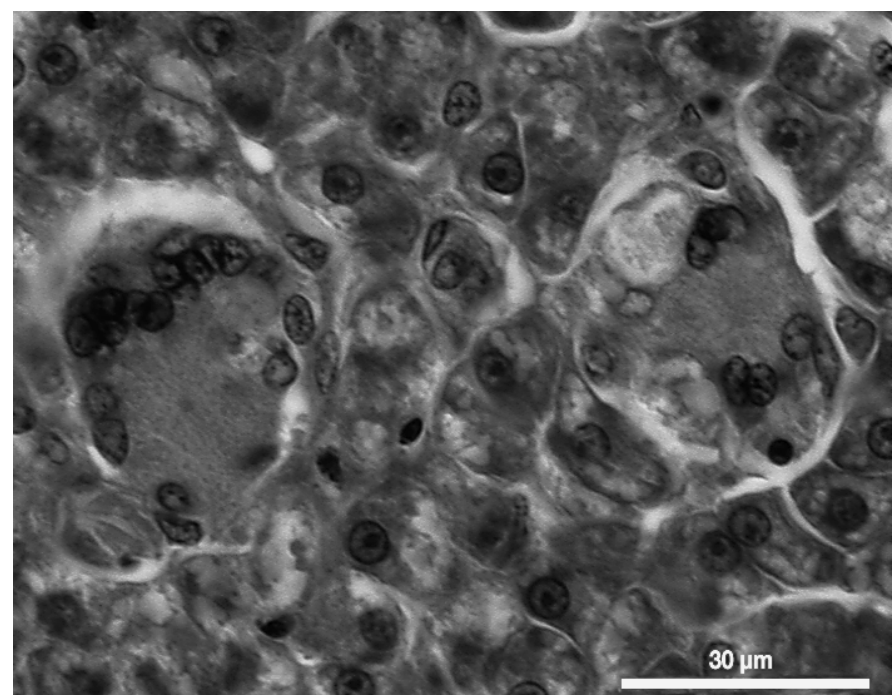

Fig. 1. Abramis brama. Section of bream liver showing 2 syncitia characterised by presence of multiple nuclei and granular cytoplasm. Marked hepatocellular necrosis evident in other regions of this specimen is not obvious in this view (haematoxylin and eosin) samples but, like the parasites, were not present in sufficient numbers to be considered as the aetiological agent of the disease outbreak. Furthermore, because of the connection between Site F and imports of bream from the River Bann, subsequent diagnostic investigations of the disease outbreak conducted at CEFAS concentrated on virological examination.

\section{Histopathological examination}

Tissues from tench from Site A and bream from Sites $\mathrm{B}$ and E were examined histologically. Only minimal histopathological changes were observed in the tissues from tench. The most frequently recorded changes, seen in 4 of the 5 tench examined, were mild to moderate gill epithelial hyperplasia and increased cellular activity in the spleen. Other pathological changes, seen in 3 of the 5 fish, included mild hepatocellular necrosis, mild to marked myocarditis, glomerulonephritis and desquamation of the mucosal epithelium in the intestine.

Examination of the bream showed minimal to marked histopathological changes in tissues from fish at Site E. Necrosis of the renal haematopoietic tissue and hepatocellular necrosis was evident in all 5 bream examined, and extensive hepatocellular necrosis was seen in 2 fish. Marked cellular necrosis was seen in the spleen of 1 bream, while the other 4 examined showed only mild degenerative changes and increased cellular activity. Other pathological changes, seen in 3 of the 5 fish, included marked degenerative changes in the nuclei of cells in the mucosal epithelium and lamina propria of the intestine, mild to moderate hyperplasia and hypertrophy of gill epithelial cells, and cellular inflammation and necrosis in neural tissue.

Histological examination of 5 bream from Site B revealed that spleen, liver, and heart tissues showed the most prominent lesions. In liver tissue from 1 fish, hepatocellular necrosis was very evident and associated with the presence of numerous syncitia which, in some cases, appeared to be formed by the fusion of hepatocytes. The syncitia contained up to 20 nuclei and were characterised by a granular eosinophilic cytoplasm (Fig. 1). An increase in melanomacrophage cells (MMC) was observed in the liver tissue of 2 other fish and, in 1 of these, a few syncitia were associated with the MMC. Splenic haemorrhaging and marked cellular activity were seen in all 5 fish examined, and syncitia formation, associated with necrotic changes, was also noted in 2 fish. In the heart tissue, degenerative changes included cellular inflammation (3 fish) and foci of cellular necrosis (2 fish). Syncitia formation associated with cell necrosis was also noted in the heart tissue of 2 fish. In total, 4 of the 5 bream exam- 
ined from Site B exhibited syncitia formation associated with cellular necrosis in different tissues. However, in further investigations we were unable to demonstrate the presence of viral antigen associated with the syncitia formation by conventional immunohistochemical methods. Other pathological changes included hyperplasia and hypertrophy of the branchial epithelial cells associated with fusion of the secondary gill lamellae (2 fish), mild to moderate renal haemorrhaging (1 fish) and degeneration of renal tubular epithelial cells (1 fish).

\section{Virus isolation and identification}

Extracts of tissue pools, sampled from a total of 6 different fish species over the 7 sites (Table 3), induced $\mathrm{CPE}$ in EPC cells at $20^{\circ} \mathrm{C}$. The CPE first appeared 2 to $4 \mathrm{~d}$ post-inoculation and was characterized by focal areas of granulation and cell-rounding which progressed over the whole cell monolayer and eventually led to cell lysis. The CPE was very similar to that described previously for SVCV and PFRV (Wolf 1988). Virus titres of 5.00 to $7.00 \log \mathrm{TCID}_{50} \mathrm{ml}^{-1}$ were recorded from 6 of the 9 virus-positive tissue pools titrated (Table 3). These titres were determined after 1 freeze/thaw cycle, so it is probable that the original virus levels in the tissues would have been higher.

In neutralisation tests, viral CPE was only partially inhibited by polyclonal rabbit antisera against SVCV and PFRV, although Isolate B062 from tench and Isolates B115 and B125/1 from bream were neutralised to a greater extent by anti-PFRV serum.

Initial virus identification was by ELISA, and viruspositive EPC harvests gave high absorbance values at $450 \mathrm{~nm}\left(A_{450}\right)$ in the PFRV EIA system but only moderate $A_{450}$ values in the SVCV EIA. When virus isolates were tested simultaneously in the 2 EIA systems, the resulting $A_{450}$ values were used to calculate a PFRV/ SVCV EIA ratio. The EIA absorbance values and the ratios of 12 isolates are listed in Table 3. A high ratio value compared to the homologous positive control virus indicates a closer antigenic relationship to PFRV than to SVCV. From Table 3 it can be seen that the PFRV/SVCV EIA ratios of the UK isolates were all below 2.0 (average 1.53, $\mathrm{n}=12$ ), whereas the reference PFRV ratio was generally above 2.0 (average $2.2, \mathrm{n}=$ 7 ). The rhabdovirus isolated from the bream mortality in the River Bann, Northern Ireland (Rowley et al. 2001) gave a PFRV/SVCV EIA ratio of 1.69. This indicates that these isolates did not share complete antigenic identity with PFRV. Analysis of partial glycopro-

Table 3. Record of virus isolations at the 7 sampling sites, spring viraemia of carp virus (SVCV) and pike fry rhabdovirus (PFRV) enzyme-immunoassay (EIA) results, and titres of virus $\left(\log \mathrm{TCID}_{50}, \mathrm{l}^{-1}\right)$ in original samples determined after 1 freeze/thaw cycle by titration in Epitheliomia papulosum cyprini (EPC) cells. $A_{450}$ : absorbance at $450 \mathrm{~nm}$ of virus-positive EPC harvests in SVCV and PFRV EIA systems; values are average readings from duplicate wells; negative (EPC cell) control values ranged from 0.013 to 0.089 and 0.042 to 0.111 in SVCV and PFRV EIA systems respectively; homologous positive control values ranged from 0.355 to 0.580 (SVCV EIA) and 0.343 to 0.588 (PFRV EIA); heterologous positive control values ranged from 0.108 to 0.218 (SVCV EIA) and 0.203 to 0.427 (PFRV EIA). $A_{450}$ ratio: $A_{450}$ value for PFRV EIA system divided by $A_{450}$ value for same harvest in SVCV EIA. Positive control virus ratios ranged from 1.60 to 2.63 for PFRV and 0.25 to 0.48 for SVCV. nd: no data (harvest tested in PFRV EIA system only)

\begin{tabular}{|c|c|c|c|c|c|c|}
\hline Site & Species & $\begin{array}{c}\text { Post-mortem } \\
\text { No./Lab. reference }\end{array}$ & $\begin{array}{c}\text { PFRV } \\
A_{450}\end{array}$ & $\begin{array}{l}\text { SVCV } \\
A_{450}\end{array}$ & $\begin{array}{c}\mathrm{PFRV} / \mathrm{SVCV} \\
A_{450} \text { ratio }\end{array}$ & $\begin{array}{c}\text { Original } \\
\text { virus titre }\end{array}$ \\
\hline A & $\begin{array}{c}\text { Tench } \\
\text { Crucian carp }\end{array}$ & $\begin{array}{l}\text { 4591/B062 } \\
\text { 4602/B074-1 }\end{array}$ & $\begin{array}{l}0.425 \\
0.397\end{array}$ & $\begin{array}{c}\text { nd } \\
0.325\end{array}$ & $\begin{array}{c}\text { nd } \\
1.22\end{array}$ & $\begin{array}{l}5.00 \\
4.50\end{array}$ \\
\hline B & Bream & $\begin{array}{l}\text { 4655/B115 } \\
\text { 4669/B133 }\end{array}$ & $\begin{array}{l}0.467 \\
0.399\end{array}$ & $\begin{array}{l}0.243 \\
0.324\end{array}$ & $\begin{array}{l}1.92 \\
1.23\end{array}$ & $\begin{array}{r}7.00 \\
<4.00\end{array}$ \\
\hline $\mathrm{C}$ & Bream & 4668/B128 & 0.478 & 0.322 & 1.48 & 5.00 \\
\hline $\mathrm{D}$ & Bream & 4691/B149 & 0.359 & 0.201 & 1.79 & nd \\
\hline $\mathrm{E}$ & $\begin{array}{l}\text { Bream } \\
\text { Roach }\end{array}$ & $\begin{array}{l}\text { 4663/B125-1 } \\
\text { 4663/B125-2 }\end{array}$ & $\begin{array}{l}0.340 \\
0.467\end{array}$ & $\begin{array}{l}0.187 \\
0.247\end{array}$ & $\begin{array}{l}1.82 \\
1.89\end{array}$ & $\begin{array}{c}5.50 \\
\text { nd }\end{array}$ \\
\hline F & Bream & $\begin{array}{l}\text { 3890/B136-2 } \\
\text { 3890/B136-9 }\end{array}$ & 0.478 & 0.315 & $\begin{array}{l}1.52 \\
1.60\end{array}$ & $\begin{array}{c}6.50 \\
\text { nd }\end{array}$ \\
\hline & $\begin{array}{l}\text { Grass carp } \\
\text { Roach }\end{array}$ & $\begin{array}{l}\text { 3890/B136-7 } \\
\text { 3890/B136-11 }\end{array}$ & $\begin{array}{l}0.467 \\
0.393\end{array}$ & $\begin{array}{l}0.358 \\
0.335\end{array}$ & $\begin{array}{l}1.30 \\
1.17\end{array}$ & $\begin{array}{c}\text { nd } \\
<4.00\end{array}$ \\
\hline G & Chub & 4737/B192/2 & 0.492 & 0.353 & 1.39 & nd \\
\hline
\end{tabular}


tein gene sequences from putative SVCV and PFRV isolates (Rowley et al. 2001, Stone et al. 2003) revealed 4 genogroups (I-IV). The English isolates and River Bann isolates shared a high degree of sequence similarity ( $\geq 99.5 \%$ nucleotide identity) and were assigned to the same genogroup (Genogroup IV).These viruses shared $<61$ and $<80 \%$ nucleotide sequence identity with SVCV and PFRV respectively. In contrast, however, these viruses showed only $10 \%$ divergence at the amino acid level when compared to the PFRV reference strain, which could account for the high degree of cross reactivity in the EIA.

\section{Virus transmission trials}

In the first trial, diseased fish were only seen in Aquarium 3 in bream injected with Isolate B125/1. We sampled 1 bream mortality at $8 \mathrm{~d}$ post-infection (p.i.), samples were taken from a moribund fish from the same group at Day 9 and a further 2 moribund fish at Day 20 p.i. No mortalities were observed in any other aquarium. Clinical signs of disease were unilateral exophthalmia, skin haemorrhages and haemorrhages around the fin bases. Histological examination revealed haemorrhages in the kidneys, livers and spleens and necrotic foci in the brains of 2 fish. Syncitia formation was also noticed, associated with cellular necrosis in pancreatic tissue, in 1 of the moribund bream sampled at Day 20 p.i. Kidney, liver and spleen tissue samples were taken for virological examination from 2 of the moribund bream, and virus was re-isolated in EPC cells from both fish.

Kidney and liver tissue extracts from the bream sampled at Days 8 and 9 gave moderately high absorbance $\left(A_{450}\right)$ values $\left(A_{450} 0.418\right.$ and 0.300$)$ in the SVCV ELISA compared to tissue extracts from shaminjected control fish $\left(A_{450}\right.$ 0.100). The same extracts gave high absorbance values $\left(A_{450}>0.550\right)$ in the PFRV ELISA, but high background absorbance values were also obtained from the sham-injected fish tissues $\left(A_{450}>0.300\right)$. From experience of a previous SVC disease outbreak (Way 1991), the $A_{450}$ values in the SVCV ELISA indicate virus levels in the tissues consistent with clinical infections. Similar low mortality rates were also observed in transmission trials with the River Bann bream isolate (Rowley et. al. 2001). In the second transmission trial, mortalities were observed in all fish species injected with Isolates B062 and B125-1 apart from tench, in which no mortalities were observed after injection with B125-1. Virus was recovered from extracts of pooled tissues, sampled from the majority (23 of 28) of the mortalities, at moderate to high titres in EPC cells. A small number of cohabitant dace mortalities were also noticed in Aquaria 1 and 4. However, virus was only isolated from 1 of 3 cohabitant dace in Aquarium 1 and from the single mortality in 4 . The cumulative mortality across all species injected with the 2 virus isolates was just less than $50 \%$. Details of the mortalities and sub-

Table 4. Fish mortality (no. dead/original no.) and virus isolation during second virus transmission. Virus titre values $=$ log $\mathrm{TCID}_{50} \mathrm{ml}^{-1}$

\begin{tabular}{|c|c|c|c|c|c|c|}
\hline \multirow{2}{*}{$\begin{array}{l}\text { Aquarium } \\
\text { no. }\end{array}$} & \multirow{2}{*}{ Virus isolate } & \multirow{2}{*}{ Fish species } & \multicolumn{2}{|c|}{ Mortalities } & \multicolumn{2}{|c|}{ Virus isolation } \\
\hline & & & i.p.-injected & Cohabitant & Virus positives & Virus titres \\
\hline \multirow[t]{3}{*}{1} & B062 & Bream & $2 / 5$ & $0 / 5$ & $2 / 2$ & $6.25 ; 6.875$ \\
\hline & & Dace & $5^{\mathrm{a}} / 5$ & $3^{\mathrm{b}} / 5$ & $4 / 5(1 / 3)$ & $\begin{array}{c}<2.50(\times 2) ; \\
4.00 ; 6.75 ;(<2.50)\end{array}$ \\
\hline & & Tench & $2 / 5$ & $0 / 5$ & $2 / 2$ & $4.25 ; 6.00$ \\
\hline \multirow[t]{3}{*}{2} & B062 & Chub & $2^{c} / 5$ & $0 / 5$ & $2 / 2$ & $<2.50 ; 5.25$ \\
\hline & & Roach & $3 \% / 5$ & $0 / 5$ & $2 / 3$ & $4.75 ; 6.25$ \\
\hline & & Tench & $2 / 5$ & $0 / 5$ & $2 / 2$ & $5.25 ; 6.75$ \\
\hline \multirow[t]{3}{*}{3} & B125-1 & Chub & $3 / 5$ & $0 / 5$ & $3 / 3$ & $4.50 ; 5.25 ; 6.75$ \\
\hline & & Roach & $3 / 5$ & $0 / 5$ & $3 / 3$ & $<2.50 ; 4.125 ; 5.50$ \\
\hline & & Bream & $3 / 5$ & $0 / 5$ & $3 / 3$ & $4.50 ; 4.625 ; 6.50$ \\
\hline \multirow[t]{3}{*}{4} & B125-1 & Dace & $2 / 5$ & $1 / 5$ & $2 / 2(1 / 1)$ & $5.00 ; 7.125 ;(5.75)$ \\
\hline & & Tench & $0 / 5$ & $0 / 5$ & & \\
\hline & & Bream & $1 / 5$ & $0 / 5$ & $1 / 1$ & 4.625 \\
\hline 5 & Sham injected & $\begin{array}{l}\text { Bream, chub, dace, } \\
\text { roach, tench }\end{array}$ & $0 / 15$ & $0 / 15$ & $0 / 5(0 / 5)$ & \\
\hline \multicolumn{7}{|c|}{$\begin{array}{l}\text { a Includes } 2 \text { mortalities on Day } 40 \text { possibly resulting from stress associated with interruption in water supply on that day } \\
{ }^{\mathrm{b} I n c l u d e s} 3 \text { mortalities on Day } 40\left(\mathrm{see}^{\mathrm{a}}\right) \\
{ }^{\mathrm{C}} \text { Includes } 1 \text { mortality on Day } 40\left(\mathrm{see}^{\mathrm{a}}\right)\end{array}$} \\
\hline
\end{tabular}


sequent virus isolation are given in Table 4. Mortalities began at Day 4 post-infection and the last mortalities were seen at Day 40 p.i., when 5 mortalities (all dace) were recorded in Aquarium 1 and 2 in Aquarium 2 (chub and roach). These late mortalities were probably a result of an interruption of the water supply to these 2 aquaria. Because of this the trial was extended to $50 \mathrm{~d}$, but no further mortalities occurred. Virus was isolated from 3 of the 7 late mortalities (2 dace, 1 chub), but was only recovered at a high titre from 1 of the dace. All survivors of the challenge trial were sampled for virus isolation at Day 50. However, virus was only recovered at very low titre from 1 dace survivor from Aquarium 4.

In the second trial, older, $1 \mathrm{yr}+$ fishes of all species tested were found to be susceptible when challenged with virus by i.p. injection. This trial also revealed that dace, roach and chub are also susceptible to Isolates B062 and B125-1. A rhabdovirus isolated from roach in the Netherlands (Isolate 80560; Haenen \& Davidse 1989, 1993) was shown to belong to the same distinct genogroup as the viruses investigated in this study (Stone et al. 2003). In virus transmission studies, the roach virus was shown to be pathogenic for fry of roach, carp and grass carp, but caused highest mortality $(>75 \%)$ in golden ide Leuciscus idus auratus fry (Haenen \& Davidse 1993). This suggests that fish of the Leuciscus genus, such as dace, chub and ide, may be more susceptible to these viruses than other cyprinid fish species.

\section{Conclusion}

There is strong evidence to suggest that the rhabdovirus isolated from bream and other cyprinid fish was responsible for the mortalities observed at the 6 fishery sites. The virus was recovered from extracts of pooled tissues at moderate to high titres in clinically diseased fish. In contrast, preliminary laboratory transmission trials indicated that the virus was of low virulence for juvenile bream. However, in the field, mortalities were observed in fish recently introduced to the sites and suffering from handling and transport stress. It is very probable that these fish were also experiencing suppression of their immune system at the low, early-spring water temperatures. The poor physiological and immunological condition of these fish very probably contributed to the severity of the disease outbreak, as has been shown in carp populations during SVC outbreaks (Fijan 1988). Further, more extensive transmission trials, using older fish, confirmed the pathogenicity of the virus for bream, tench and roach but mortality was also seen in dace and chub. No similar disease outbreaks were reported in England during spring 2000. However, to determine whether there were any virus carriers in the populations, fish from 5 of the 6 sites were re-sampled for virus isolation and virus detection by RT-PCR during May 2000. No viruses were detected by these methods in any of the fish species sampled.

Serological and molecular virology studies have shown that the rhabdovirus isolated on the English sites is identical to the rhabdovirus isolated from bream in the River Bann and that these viruses are similar but not identical to PFRV. Using diagnostic tests currently recommended by the OIE, these viruses could also be mis-diagnosed as SVC virus. The involvement of this rhabdovirus in the disease outbreaks in Northern Ireland and England is confirmation that aquatic vesiculo-like viruses other than SVC virus can cause major mortalities in cyprinid fish populations.

Acknowledgement. This work was supported by DEFRA, contracts F1136, F1118 and FA001.

\section{LITERATURE CITED}

Ahne W (1975) A rhabdovirus isolated from grass carp (Ctenopharyngdon idella Val.). Arch Virol 48:181-185

Ahne W (1986) Unterschiedliche biologische Eigenschaften 4 cyprinidenpathogener Rhabdovirusisolate. J Vet Med Ser B 33:253-259

Ahne W, Mahnel H, Steinhagen P (1982) Isolation of pike fry rhabdovirus from tench, Tinca tinca (L.) and white bream Blicca bjoernka (L.). J Fish Dis 5:535-537

Fijan N (1988) Vaccination against spring viraemia of carp. In: Ellis AE (ed) Fish vaccination. Academic Press, London, p 204-215

Fijan N, Petrinec Z, Sulimanovic D, Zwillenberg LO (1971) Isolation of the viral causative agent from the acute form of infectious dropsy of carp. Vet Arh 41:125-138

Fijan N, Sulimanovic D, Bearzotti M, Muzinic D, Zwillenberg LO, Chilmoncyzk S, Vautherot JF, Kinkelin P de (1983) Some properties of the Epithelioma papulosum cyprini (EPC) cell line from carp Cyprinus carpio. Ann Virol 134E: 207-220

Fijan N, Matasin Z, Jeney Z, Olah J, Zwillenberg LO (1984) Isolation of Rhabdovirus carpio from sheatfish (Silurus glanis) fry. Symp Biol Hung 23:17-24

Haenen OLM, Davidse A (1989) Isolation of a pike fry rhabdovirus from roach (Rutilis rutilis). Bull Eur Assoc Fish Pathol 9:116

Haenen OLM, Davidse A (1993) Comparative pathogenicity of two strains of pike fry rhabdovirus and spring viremia of carp virus for young roach, common carp, grass carp and rainbow trout. Dis Aquat Org 15:87-92

Hill BJ, Williams RF, Finlay J (1981) Preparation of antisera against fish virus disease agents. Dev Biol Stand 49: 209-218

Kölbl O (1975) Neue Erkenntnisse über die Bauchwassersucht bei Karpfen. Österr Fischerei 28:69-72

OIE (Office International Des Epizooties) (2000) Diagnostic manual for aquatic animal diseases, 3nd edn. OIE, Paris, p 46-52 
Reed LJ, Muench H (1938) A simple method of estimating fifty percent endpoints. Am J Hyg 27:493-502

Rowley H, Graham DA, Campbell S, Way K, Stone DM, Curran WL, Bryson DG (2001) Isolation and characterisation of rhabdovirus from wild common bream (Abramis brama) and roach (Rutilus rutilus) and from farmed brown trout (Salmo trutta) and rainbow trout (Oncorhynchus mykiss) in Northern Ireland. Dis Aquat Org 48:7-15

Rudikov NI (1980) La virose printanière des poissons en URSS. Bull Off Int Epizoot 92:1069-1077

Rudikov NI, Grischenko LI, Lobuntsov KA (1975) Spring viral

Editorial responsibility: Jo-Ann Leong,

Kaneohe, Hawaii, USA disease of fish. Byull Ves Inst Eksp Vet 20:16-19 (in Russian) Stone DM, Ahne W, Denham KL, Dixon PF, Liu CTY, Sheppard AM, Taylor GR, Way K (2003) Nucleotide sequence analysis of the glycoprotein gene of putative spring viraemia of carp virus and pike fry rhabdovirus isolates reveals four genogroups. Dis Aquat Org 53:203-210

Way K (1991) Rapid detection of SVC virus antigen in infected cell cultures and clinically diseased carp by the enzymelinked immunosorbent assay (ELISA). J Appl Ichthyol 7: 95-107

Wolf K (1988) Fish viruses and fish viral diseases. Cornell University Press, Ithaca, NY, p 177-216

Submitted: December 22, 2001; Accepted: July 1, 2003

Proofs received from author(s): September 6, 2003 